VIỆN HÀN LÂM KHOA HỌC VÀ CÔNG NGHỆ VIỆT NAM VIETNAM ACADEMY OF SCIENCE AND TECHNOLOGY

ISSN 1859-3097

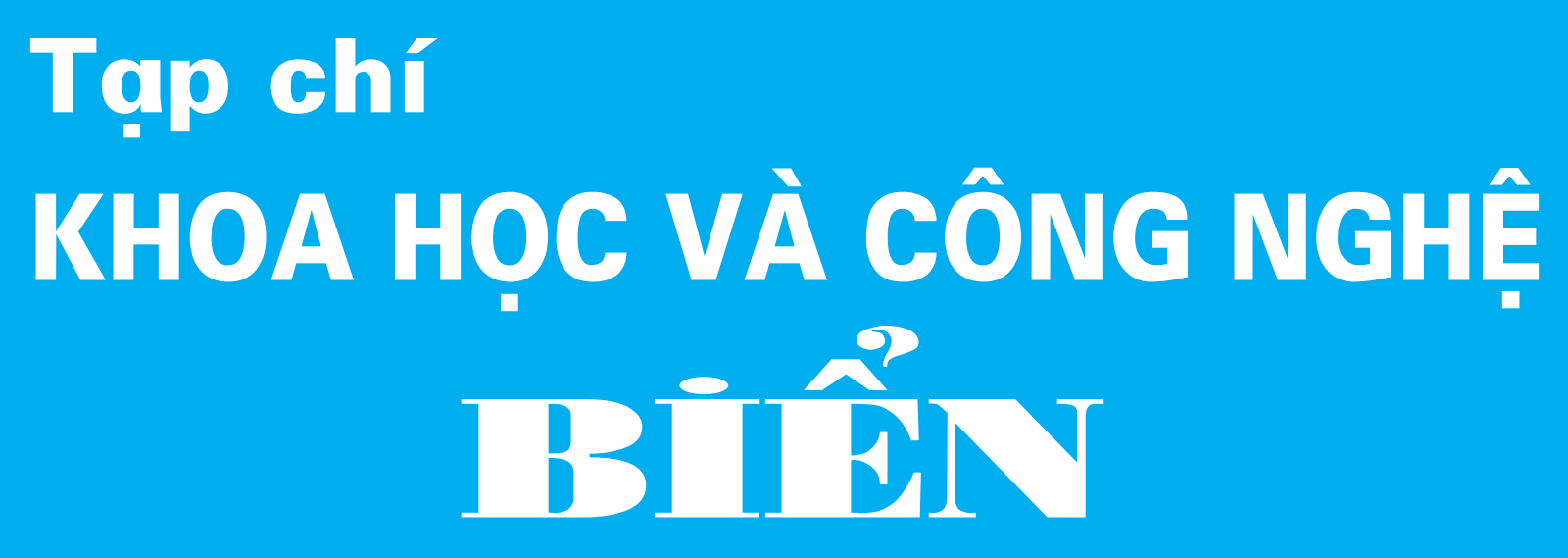

JOURNAL OF MARINE SCIENCE AND TECHNOLOGY

$\frac{2(\mathrm{~T} .14)}{2014}$

HÀ NỘI 


\title{
ẢNH HƯỞNG CỦA MANNAN OLIGOSACCHARIDE BỔ SUNG VÀO THỨC ĂN LÊN PROTEIN TRONG CƠ, HİNH THÁI RUỘT VÀ TÊ BÀO MÁU CỦA CÁ KHOANG CỔ NEMO, AMPHIPRION OCELLARIS
}

\author{
Đỗ Hữu Hoàng*, Hoàng Đức Lư, Phạm Xuân Kỳ, Đặng Trần Tú Trâm, Nguyễn Thị Kim \\ Bích, Hồ Sơn Lâm, Trần Văn Huynh, Đào Việt Hà, Nguyễn Thu Hồng, Phan Bảo Vi \\ Viện Hải dương học, Viện Hàn lâm Khoa học và Công nghệ Việt Nam \\ E-mail: dohuuhoang2002@yahoo.com
}

Ngày nhận bài: 17-2-2014

\begin{abstract}
TÓM TÄT: Cá khoang cổ (Amphiprion ocellaris) $(22,4$ cm) được nuôi trong hệ thống lọc tuần hoàn thể tích 50 lít, mật độ 20 con/bể và cho ăn trong 10 tuần bằng các thức ăn có bổ sung 6 nồng độ mannan oligosaccharide (MOS): đối chứng, 0,05\%;0,10\%; 0,15\%;0,20\%; 0,25\% và lô bổ sung 0,30\%. Các chỉ tiêu đo đạc bao gồm: tỷ lệ chu vi bên trong và bên ngoài thành ruôt, hàm luợng protein trong cơ và tế bào máu tổng số. Kết quả nghiên cứu cho thấy, tỷ lệ chu vi thành ruột cá cao nhất ở lô có hàm luợng MOS 0,10\% và 0,15\% tỷ lệ này thấp nhất ở lô đối chứng và lô bổ sung 0,3\% $\operatorname{MOS}(P<0,05)$. Ở nồng độ thấp hơn hoạc cao hơn $0,1-0,15 \%$ cá đều có diện tích bề mặt thành ruột thấp $(P<0,05)$. Sau 4 tuần nuôi hàm luợng protein trong co cá dao động tù $12,85 \%$ đến 15,53\%P. Protein trong co cá ở tuần thứ 10 cao hơn so với tuần thứ 4, nhưng không sai khác $(P>0,05)$ và hàm luợng protein cũng không có khác nhau có ý nghĩa thống kê giũa các lô thí nghiệm ở các lần đo (tuần 1 và tuần 10$)(P<0,05)$.Tổng số tế bào máu cá ở tuần thú 10 cao nhất ở lô cho ăn $0,05 \% \quad\left(26,22 \times 10^{5} \pm 2,80 \times 10^{5} \mathrm{tb} / \mathrm{mm}^{3}\right)$ kế đến là nghiệm thíc bổ sung $0,25 \%$ MOS và $0,10 \%$ MOS đạt giá tri lần luột là $21,54 \times 10^{5} \pm 3,65 \times 10^{5} \mathrm{tb} / \mathrm{mm}^{3}$ và $20,73 \times 10^{5} \pm 7,88 \times 10^{5} \mathrm{tb} / \mathrm{mm}^{3}$. Mật độ tế bào máu thấp nhất ở lô cá cho ăn $0,15 \%$ MOS $\left(11,02 \times 10^{5} \pm 2,00 \times 10^{5}\right.$ tb/mm $)$. Mật độ tế bào máu sai khác có ý nghĩa thống kê giữa lô cho ăn 0,05\% MOS (lô 2) so với lô đối chứng MOS và lô cá bổ sung 0,15\% MOS $(P<0,05)$.
\end{abstract}

Tù khoá: Cá khoang cổ, Amphiprion ocellaris, mannan oligosaccharide, hình thái ruột, protein, tế bào máu.

\section{MỞ ĐÀU}

Cá khoang cổ thuộc họ Pomacentridae là loài cá cảnh biển có giá trị thương mại và chúng được nuôi làm cảnh phổ biến vì chúng có màu sắc đẹp. Loài cá khoang cổ nemo (Amphirion ocellaris) được cho sinh sản nhân tạo thành công trong điều kiện nuôi nhốt. Tuy nhiên trong quá trình nuôi cá thường bỏ ăn, cá con chậm lớn, tỷ lệ sống thấp. Vì vậy, tìm kiếm giải pháp nâng cao tốc độ sinh trưởng và tỷ lệ sống cá khoang cổ con là vấn đề cần thiết hiện nay. Trong quá trình nuôi, khi cá bị bệnh, kháng sinh hoặc hóa chất thường được sử dụng. Đây là giải pháp tức thời và tác động xấu tới môi trường. Nhiều công trình nghiên cứu đã chứng minh bổ sung prebiotics có thể làm tăng tốc độ sinh trưởng và sức khoẻ vật nuôi. Tuy nhiên, chưa có công trình nghiên cứu bổ sung chế phẩm sinh học đặc biệt là mannan oligosaccharide lên cá khoang cổ.

Prebiotics là loại dưỡng chất chuyên biệt dành cho một số nhóm sinh vật có lợi cho cơ thể vật chủ. Thông qua việc cung cấp dinh dưỡng một cách có chọn lọc cho một hoặc một 
số vi sinh vật có lợi trong đường ruột, prebiotic làm thay đổi có chọn lọc hệ vi sinh vật đường ruột của vật chủ. Prebiotic còn được xem là chẩt kích thích hệ miễn dịch của vật chủ [16]. Mannan oligosaccharide (MOS), là một loại prebiotic tự nhiên, được chiếc xuất từ thành tế bào nấm men (Saccharomyces cereviciae), được sử dụng nhiều trong chăn nuôi gia súc, gia cầm. Kết quả nghiên cứu cho thấy bổ sung mannan oligosaccharides vào thức ăn đã cho nhiều hiệu quả tích cực đối với nhiều loài thủy sản khác nhau như: cá bơn [7], cá tầm [3], cá tráp [10]; cá da trơn [15], cá hồi [6, 7], cá chép cảnh $[1,2]$.

Nhằm cung cấp cơ sở khoa học cho việc sử dụng Mannan oligosaccharide (MOS) bổ sung vào thức ăn để tăng cường sức khỏe của cá nuôi, chúng tôi bố trí thí nghiệm nghiên cứu ảnh hưởng của các nồng độ MOS bổ sung vào thức ăn lên hình thái ruột, hàm lượng protein và tế bào máu của cá khoang cổ nemo, Amphiprion ocellaris ở giai đoạn con non.

\section{VÂT LIẸU VÀ PHƯƠNG PHÁP NGHIÊN CứU}

\section{Hệ thống nuôi và cá thí nghiệm}

Hệ thống nuôi: tổng số 21 bể thủy tinh, thể tích 50 lít, phân chia thành 3 hệ thống lọc tuần hoàn, từ đó chúng tôi đo các yếu tố môi trường theo 3 hệ thống này. Mỗi bể nhỏ và bể lọc tuần hoàn đều có gắn hệ thống sục khí 24/24. Tốc độ nước chảy ở mỗi bể khoảng 0,5 lít/phút. Sử dụng cá khoang cổ nemo (Amphiprion ocellaris), khỏe mạnh có kích thước trung bình $24,15 \mathrm{~mm}$, chọn lọc từ trại sản xuất giông cá khoang cổ, phòng Công nghệ nuôi trồng. Thí nghiệm tiến hành tại Trạm thực nghiệm và cơ sở nuôi của phòng Công nghệ Nuôi trồng Viện Hải dương học từ tháng 5/2013 đến tháng $11 / 2013$.

\section{Chuẩn bị thức ăn thí nghiệm}

Sử dụng thức ăn công nghiệp Lansy (đạm $40 \%$, lipid $9 \%, 2,5 \%$ xơ, kích thước hạt $\sim 0,8 \mathrm{~mm}$ ) làm thức ăn đối chứng. Thức ăn trền có hàm lượng và thành phần dinh dưỡng chính phù hợp cho cá cảnh $[14,17]$. Sử dụng chế phẩm thương mại Bio-Mos ${ }^{\circledR}$ (Alltech, USA). Sử dụng 6 hàm lượng MOS khác nhau $(0,05$; $0,10 ; 0,15 ; 0,2 ; 0,25 ; 0,3 \%)$ bổ sung vào thức ăn tổng hợp Lansy, để khô và bảo quản ở $4^{0} \mathrm{C}$ cho đến khi sử dụng.

\section{Bố trí thí nghiệm}

Cá thí nghiệm được thả ngẫu nhiên vào bể thí nghiệm với số lượng 20 con mỗi bể và được nuôi thích nghi 7 ngày trước khi tiến hành thí nghiệm. Thí nghiệm bao gồm 7 nghiệm thức và 3 lần lặp cho mỗi nghiệm thức. Từng nhóm 3 bể thí nghiệm được chọn ngẫu nhiên và cho ăn 1 loại thức ăn có hàm lượng MOS trên và nuôi trong 10 tuần. Thu mẫu đếm tế bào máu (2 tuần/lần), protein trong cơ phân tích lúc bắt đầu, tuần 4 và tuần 10 , thu mẫu ruột ở tuần thứ 10 .

\section{Chăm sóc và quản lý cá thí nghiệm}

Cá sẽ cho ăn mỗi ngày 2 lần vào buổi sáng và buổi chiều. Lượng thức ăn được cung cấp theo nhu cầu của cá bằng cách quan sát trực tiếp. Trong suốt thời gian thí nghiệm: nhiệt độ dao động trong khoảng $28,5-29,9^{\circ} \mathrm{C}, \mathrm{pH}$ dao động trong khoảng: 7,8 - 8,1. Độ mặn nằm trong khoảng $33,81-34,45 \%$ o và $\mathrm{NH}_{4} / \mathrm{NH}_{3}$ nằm trong khoảng $0-0,25 \mathrm{ppm}$.

\section{Thu thập và xử lý số liệu}

Tỷ lệ chu vi trong và ngoài thành ruột: Mẫu ruột cá thu mỗi bể 1 con (3 con mỗi nghiệm thức) vào lúc kết thúc thí nghiệm (tuần 10). Giải phẫu và cố định ruột cá trong dung dịch formol $10 \%$ trước khi tiến hành cắt tiêu bản. Tiêu bản được quan sát dưới kính hiển vi Olympus CX 31 ở độ phóng đại 100 lần và được chụp bằng máy ảnh Olympus E330. Đo chu vi mặt trong và ngoài thành ruột (mỗi lô đo 5 mẫu) của cá bằng phần mềm ImageJ, theo phương pháp của Dimitroglou et al. [6]. Tỷ lệ chu vi bên ngoài và chu vi bên trong thành ruột (PR) được tính theo công thức: $P R=a / b$. Trong đó: a: chu vi trong của ruột.; b: chu vi ngoài của ruột.

Hàm lượng protein trong cơ cá khoang cổ nemo: Mẫu phân tích protein trong cơ cá được thu vào lúc bắt đầu thí nghiệm, tuần thứ 4 và tuần thứ 10. Mỗi bể thu ngẫu nhiên 1 cá thể, tổng số mẫu cho mỗi nghiệm thức là 3 ở mỗi lần thu mẫu. Hàm lượng protein tổng số trong cơ cá được phân tích dựa theo phương pháp của Bradford (1976). 
Tế bào máu tổng số: Mật độ tế bào máu cá được thu lúc kết thú thí nghiệm, mỗi bể thu ngẩu nhiên 1 cá thể, số mẫu là 21 cá thể. Máu được thu từ tĩnh mạch đuôi bằng ống tiêm $1 \mathrm{~mL}$, có chứa sẵn $0,2 \mathrm{~mL}$ nước muối sinh lý làm chất chống đông máu. Thể tích máu thực tế mỗi lần hút được ghi lại để tính tỷ lệ pha loãng. Đếm máu bằng buồng đếm hồng cầu Neubauer Improved Bright-line dưới kính hiển vi ở độ phóng đại 400 lần. Mật độ hồng cầu được tính theo công thức sau: Mật độ tế bào máu $\left(\mathrm{HC} / \mathrm{mm}^{3}\right)=\mathrm{A} \times 4000 \times \mathrm{B} / 80$. Trong đó: $\mathrm{A}:$ tổng số lượng tế bào máu đếm được trên 5 ô đếm lớn hay 80 ô đếm nhỏ (mỗi ô đếm lớn có 16 ô nhỏ); B: hệ số pha loãng; Thể tích 1 ô đếm nhỏ là $1 / 4000 \mathrm{~mm}^{3}$ (diện tích 1 ô nhỏ: $1 / 400 \mathrm{~mm}^{2}$, chiều dày từ mặt buồng đếm đến lamelle: $1 / 10 \mathrm{~mm}$ ).

Thống kê số liệu: Tính toán giá trị trung bình, sai số, tỷ lệ sống bằng phần mềm Excel. So sánh hàm lượng protein trong cơ, tỷ lệ chu vi thành ruột và số lượng tế bào máu của cá nuôi giữa các lô thí nghiệm bằng phương pháp phân tích phương sai (ANOVA). Giá trị $\mathrm{P} \leq$ 0,05 được xem là khác nhau có ý nghĩa thống kê giữa các giá trị trung bình.

\section{KÊT QUẢ}

\section{Một số yếu tố môi trường trong bể thí nghiệm}

Qua bảng 1 thấy rằng trong suốt thời gian thí nghiệm nhiệt độ dao động trong khoảng $28,5-30^{\circ} \mathrm{C}, \mathrm{pH}$ dao động trong khoảng: 8 8,3. Độ mặn nằm trong khoảng 34 - 35\%o, $\mathrm{NH}_{4} / \mathrm{NH}_{3}$ nằm trong khoảng $0-0,25 \mathrm{mg} / \mathrm{L}$ và $\mathrm{NO}_{3}$ dao động từ $0-0,25 \mathrm{mg} / \mathrm{L}$. Theo các nghiên cứu trước đây, các yếu tố môi trường trong bể thí nghiệm (bảng 1 ) đều nằm trong ngưỡng cho phép và không ảnh hưởng đến sự tăng trưởng và tỷ lệ sống của cá khoang cổ nemo (Hà Thị Lê Lộc, 2005).

Bảng 1. Các yếu tố môi trường trong bể thí nghiệm.

\begin{tabular}{|c|c|c|c|c|}
\hline Nhiệt độ ( $\left.{ }^{\circ} \mathrm{C}\right)$ & Độ mặn (\%o) & $\mathrm{pH}$ & $\mathrm{NH}_{4} / \mathrm{NH}_{3}(\mathrm{mg} / \mathrm{L})$ & $\mathrm{NO}_{3}(\mathrm{mg} / \mathrm{L})$ \\
\hline $28,5-30^{\circ} \mathrm{C}$ & $34-35$ & $8-8,3$ & $0-0,1$ & $0-0,25$ \\
\hline
\end{tabular}

Hình thái ruột của cá nemo khi cho ăn các hàm lượng MOS khác nhau

Bảng 2: Tỷ lệ chu vi bên trong và chu vi bên ngoài thành ruột $(\mathrm{PR})$ của cá nemo ở tuần 10

\begin{tabular}{cc}
\hline Lô thí nghiệm & PR \\
\cline { 2 - 2 } 1 & $1,66 \pm 0,71^{\mathrm{a}}$ \\
2 & $1,72 \pm 0,09^{\mathrm{a}}$ \\
3 & $2,17 \pm 0,09^{\mathrm{b}}$ \\
4 & $2,12 \pm 0,15^{\mathrm{b}}$ \\
5 & $1,80 \pm 0,05^{\mathrm{a}}$ \\
6 & $1,70 \pm 0,11^{\mathrm{a}}$ \\
7 & $1,62 \pm 0,05^{\mathrm{a}}$ \\
\hline
\end{tabular}

Lô 1: đối chưng, Lô 2: 0,05\%, Lô 3: 0,10\%, Lô 4: 0,15\%, Lô 5: 0,20\%, Lô 6: 0,25\%, Lô 7: 0,3\%.

Số liệu trình bày là giá trị trung bình \pm sai số. Số liệu cùng cột có các chũ cái khác nhau thể hiện sai khác có ý nghĩa thống kê $(P<0,05)$

Tỷ lệ giữa chu vi bên trong và chu vi bên ngoài đạt giá trị cao nhất ở lô 3 và 4 (lần lượt là $2,12 \pm 0,15$ và $2,17 \pm 0,09)$ và thấp nhất ở lô 1 và lô 7 (giá trị lần lượt là $1,66 \pm 0,71$ và $1,62 \pm$ $0,05)$. Tỷ lệ này không có sự sai khác có ý nghĩa thông kê giữa các lô $1,2,5,6$ và $7(\mathrm{P}>$ $0,05)$ và giữa lô 3 và lô $4(\mathrm{P}>0,05)$. Tuy nhiên, tỷ lệ giữa chu vi bên trong và chu vi bên ngoài của cá ở lô 3 và lô $4(0,10 \%$ và $0,15 \%$ MOS) cao hơn so với các lô còn lại $(\mathrm{P}<0,05)$ (bảng 2, hình 1). 
Đỗ Hữu Hoàng, Hoàng Đức Lư, ...
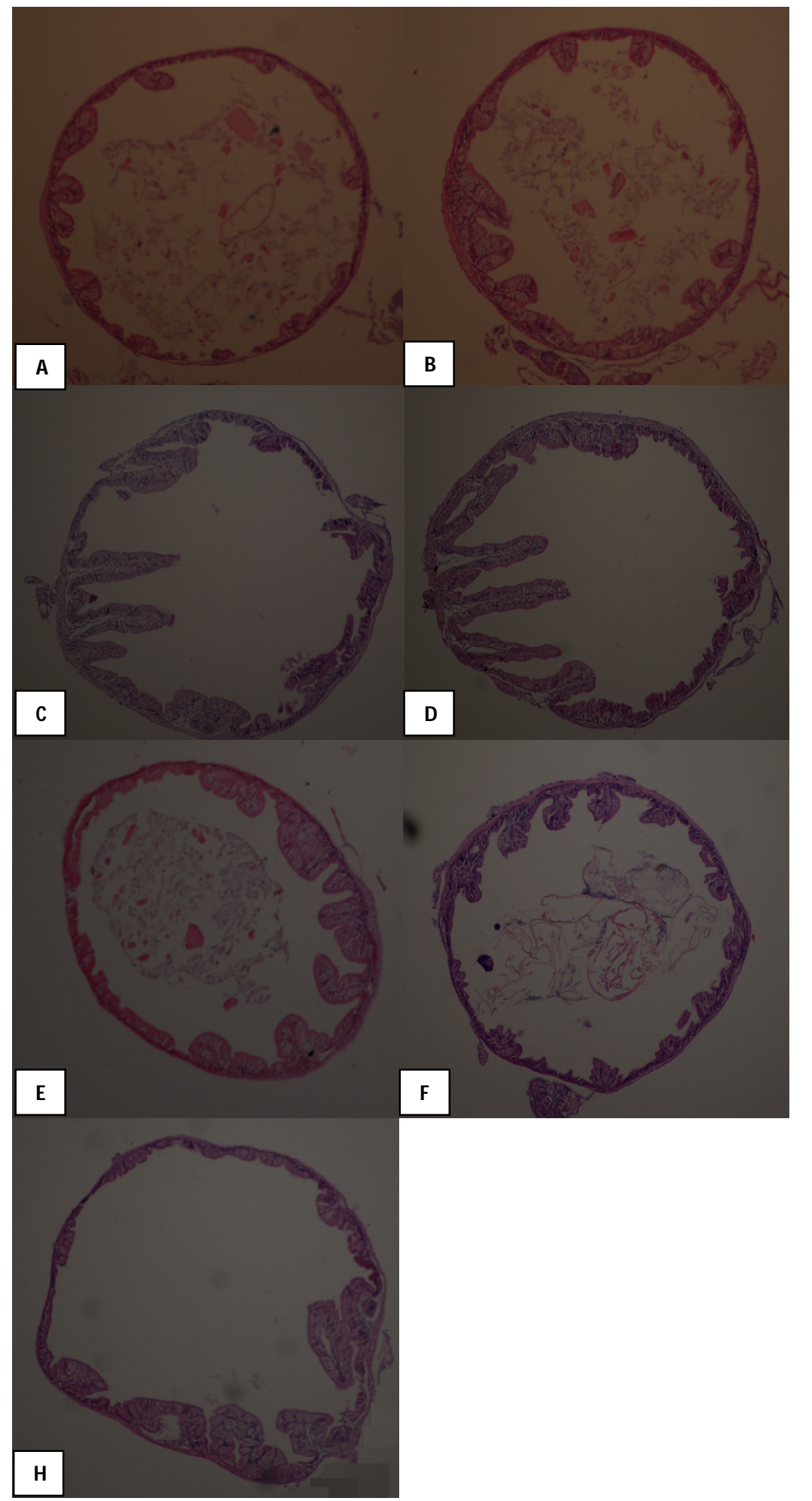

Hình 1. Lát cắt ngang mô ruột cá khoang cổ nemo ở tuần 10

Trong đó: $A, B, C, D, E, F$ và H lần lượ là các lô thí nghiệm 1, 2, 3, 4, 5, 6 \& 7. Lô 1: đối chúng, Lô 2: 0,05\%, Lô 3: 0,10\%, Lô 4: 0,15\%, Lô 5: 0,20\%, Lô 6: 0,25\%, Lô 7: 0,3\% 


\section{Hàm lượng protein trong cơ của cá nemo}

Hàm lượng protein trung bình của cá lúc bắt đầu thí nghiệm là $12,33 \%$. Sau 4 tuần cho ăn, hàm lượng protein thấp nhất ở lô đối chứng (lô1) và lô $3(0,10 \% \mathrm{MOS})$ giá trị lần lượt là $12,85 \% \mathrm{P}$ và $12,64 \% \mathrm{P}$; hàm lượng protein cao nhất ở các lô $4(0,15 \% \mathrm{MOS})$ và lô $5(0,20 \%$ MOS), lần lượt là $15,34 \% \mathrm{P}$ và $15,53 \% \mathrm{P}$. Hàm lượng protein có $\mathrm{xu}$ hướng tăng theo thời gian (tuần 10 cao hơn tuần thứ 4 ) trong cùng 1 lô thức ăn. Tuy nhiên, kết quả phân tích protein ở tuần thứ 4 và tuần 10 , không có sự sai khác có ý nghĩa thống kê giữa hàm lượng protein trong cơ cá khoang cổ nemo ở các lô thí nghiệm khác nhau $(\mathrm{P}>0,05)$. Duy nhất nhóm cá nemo ăn bổ sung $0,2 \%$ MOS có hàm lượng protein trong cơ ở tuần 10 cao hơn có ý nghĩa so với tuần thứ 4 ( $\mathrm{P}<0,05)$ (hình 2).

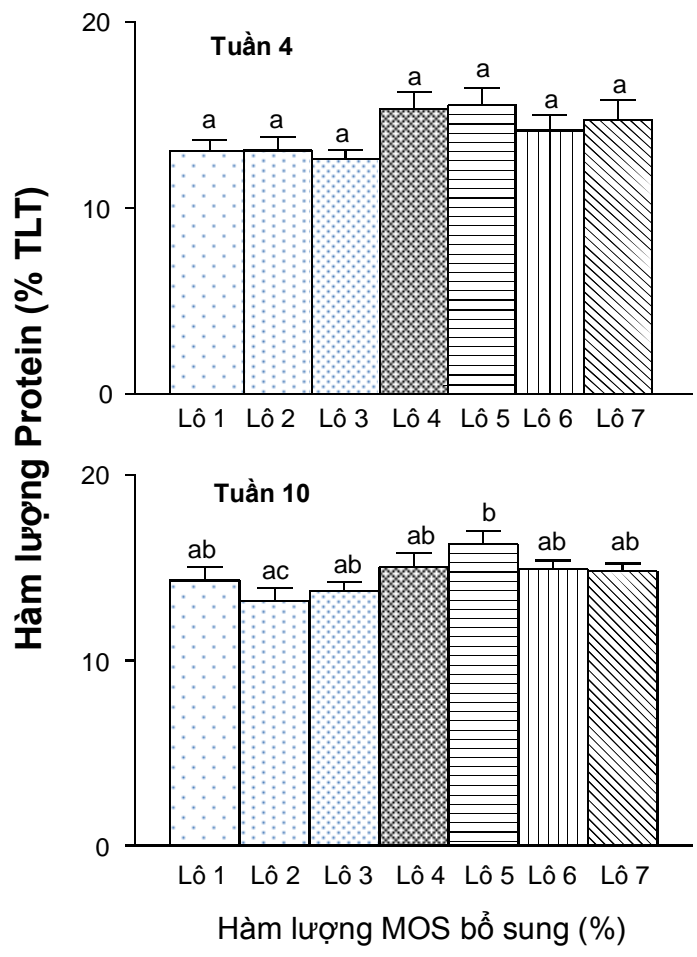

Hình 2. Hàm lượng protein (\% TL T) của cá khoang cổ nemo ở các lô thí nghiệm Lô 1: đối chứng, Lô 2: 0,05\%, Lô 3: 0,10\%, Lô 4: 0,15\%, Lô 5: 0,20\%, Lô 6: 0,25\%, Lô 7: 0,3\%.

Số liệu trình bày là giá trị trung bình \pm sai số. Số liệu có các chĩ cái khác nhau thể hiện sai khác có ý nghĩa thống kê $(P<0,05)$

\section{Mật độ tế bào máu của cá nemo}

Vào tuần thứ 10 ở tất cả các nghiệm thức, mật độ tế bào máu đạt giá trị cao nhât $\left(26,22 \times 10^{5} \pm\right.$ $\left.2,80 \times 10^{5} \mathrm{tb} / \mathrm{mm}^{3}\right)$ tại nghiệm thức bồ sung $0,05 \%$ MOS (lô 2), kế đến là nghiệm thức bổ sung $0,25 \%$ MOS (lô 6) và $0,10 \% \operatorname{MOS}$ (lô 3) đạt $21,54 \times 10^{5} \pm$ $3,65 \times 10^{5} \mathrm{tb} / \mathrm{mm}^{3}$ và $20,73 \times 10^{5} \pm 7,88 \times 10^{5} \mathrm{tb} / \mathrm{mm}^{3}$, mật độ tế bào máu cá thấp nhất $\left(11,02 \times 10^{5} \pm\right.$ $\left.2,00 \times 10^{5} \mathrm{tb} / \mathrm{mm}^{3}\right)$ ở nghiệm thức $0,15 \%$ MOS (lô 4). Tế bào máu sai khác có ý nghĩa giữa lô cho ăn bồ sung $0,05 \%$ MOS (lô 2) so với lô đối chứng $0,0 \%$ MOS và lô cho ăn thức ăn có bổ sung $0,15 \%$ MOS (lô 4) (P < 0,05) nhưng không có sự khác biệt có ý nghĩa giữa với các nghiệm thức bổ sung $0,1 \%$, $0,20 \% ; 0,25 \%$ và $0,30 \% \operatorname{MOS}(\mathrm{P}>0,05)$ (hình 3 ).

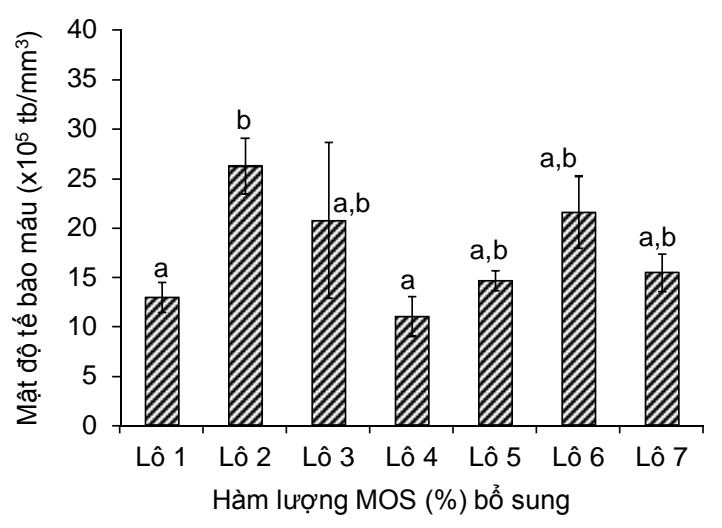

Hình 3. Mật độ tế bào máu cá nemo (tb $\mathrm{x} 10^{5} / \mathrm{mm}^{3}$ ) ở các lô bổ sung MOS khác nhau Lô 1: đối chúng, Lô 2: 0,05\%, Lô 3: 0,10\%, Lô 4: 0,15\%, Lô 5: 0,20\%, Lô 6: 0,25\%, Lô 7: 0,3\%

Số liệu trình bày là giá trị trung bình \pm sai số. Số liệu có các chũ cái khác nhau thể hiện sai khác có ý nghĩa thống kê $(P<0,05)$

\section{THẢO LUẬN}

Bề mặt thành ruột là nơi hấp thu chất dinh dưỡng và trao đổi năng lượng và vật chất quan trọng của cơ thể. Diện tích bề mặt ruột lớn và khỏe mạnh giúp quá trình trao đổi chất hiệu quả hơn, làm giảm năng lượng tiêu hóa (Sweetman và cs., 2008). Ngoài ra, thành ruột là nơi các vi sinh vật gây bệnh dễ dàng xâm nhập vào cơ thể vật chủ. Thành ruột khỏe mạnh, với hệ vi sinh vật có lợi sẽ làm tăng hiệu quả trao đổi dinh dưỡng và sức kháng của vật chủ. Nhiều nghiên cứu cho thấy hình thái ruột của cá cũng thay đổi khi cá bị nhiễm vi khuẩn gây bệnh (Ringo 
và cs., 2007; Ringo và cs., 2004). Tỷ lệ giữa chu vi bên trong và bên ngoài ống tiêu hoá của cá là một trong những chỉ tiêu được sử dụng phổ biến để đánh giá hình thái của ruột cá và giáp xác [5-8, 18].

Kết quả nghiên cứu của chúng tôi cho thấy có sự ảnh hưởng rõ rệt của hàm lượng MOS bồ sung và hình thái ruột của cá khoang cố sau 10 tuần nuôi. Kết quả này cũng phù hợp với các kết quả nghiên cứu trên các loài cá khác cho thấy chu vi thành ruột của vật nuôi cũng tăng rõ rệt khi bổ sung MOS vào thức ăn của chúng [68]. Kết quả đề tài cơ sở năm 2012 cũng cho thấy cá khoang cổ cho ăn MOS cũng có tỷ lệ chu vi thành ruột tăng rất nhiều so với lô đối chứng (Kiên và cs 2012).

Hàm lượng protein trong cơ là một trong những chỉ thị quan trọng đánh giá điều kiện dinh dưỡng và sức khỏe của cá [13]. Dinh dưỡng cân bằng giúp cá sinh trưởng nhanh và hàm lượng protein trong cơ cũng cao hơn. Kết quả phân tích hàm lượng protein trong cơ cá nemo khi cho ăn bổ sung các hàm lượng MOS không sai khác nhau có ý nghĩa thống kê. Kết quả này tương tự như các kêt quả nghiên cứu trên cá tầm, Huso huso (Razeghi và cs., 2012), cá tráp vàng, Sparus aurata (Dimitroglou và cs., 2010) [10], cá tráp mõm ngắn, Diplodus puntazzo (Piccolo và cs., 2013). Các nghiên cứu này cho thấy việc bổ sung MOS không làm thay đồi hàm lượng protein của cá. Tuy nhiên, một số công trình khác kết luận rằng hàm lượng protein trong cơ cá cho ăn MOS cao hơn hẳn so với cá không cho ăn như trên cá chép cảnh [2], cá hồi (Oncorhynchus mykiss) và cá rô phi lai (Oreochromis niloticus $\times O$. aureus) [9], cá chẽm (Dicentrarchus labrax) (Torrecillas và cs., 2007). Đối với cá hồi Đại Tây Dương, Salmo sarla, khi bổ sung MOS vào thức ăn thì hàm lượng protein trong cá lại giảm hơn 5\% (Grisdale-Helland và cs., 2008). Theo nhận định của Grisdale-Helland và cs. (2008) ảnh hưởng của MOS lên hàm lượng protein của cá có thể tuỳ thuộc vào đặc tính của từng loài.

Tế bào máu được xem là một chỉ tiêu quan trọng để đánh giá sức khỏe của cá nuôi [4]. Tế bào máu của vật nuôi có thể bị ảnh hưởng tuỳ thuộc vào tình trạng dinh dưỡng, sức khoẻ, biến động các yếu tố môi trường và kích thước sinh vật. Kết quả bước đầu nghiên cứu ảnh hưởng của MOS trên cá khoang cổ nemo trong báo cáo này cho thấy MOS có thể làm thay đổi số lượng tế bào máu cá nemo. Tuy nhiên, số liệu còn nhiều dao động lớn. Mức độ ảnh hưởng bởi hàm lượng MOS bổ sung qua các mốc thời gian không có xu thể rõ ràng. Nguyên nhân khác có thể do kích thước cá có kích thước nhỏ, thể tích máu thu được rất ít làm ảnh hưởng đến sai số khi đọc thể tích máu thu được.

Kết quả nhiên cứu của chúng tôi cho thấy mật độ tể bào máu của cá nemo chịu ảnh bởi hàm lượng MOS bổ sung. Kết quả này phù hợp với nhiều nghiên cứu trên các loài cá khác như cá chép $[1,2]$, cá tầm [3], cá trôi (Andrews và cs., 2009). Tuy nhiên, một số công trình nghiên cứu cho thấy việc bổ sung MOS không ảnh hưởng đến các các chỉ số huyết học đối với các loài khác. Taati và cs. (2011) nhận định rằng sự thay đổi các chỉ số tế bào máu có thể chịu ảnh hưởng bởi nhiều nhân tố khác nhau như đặc tính của từng loài, hàm lượng MOS bổ sung và thời gian cho ăn bổ sung.

Kết quả bước đầu cho thấy bổ sung MOS làm tăng diện tích bề mặt của thành ruột của khoang cổ nemo sau 10 tuần nuôi, làm thay đổi hàm lượng tế bào máu, tuy nhiên hàm lượng protein trong cơ cá không khác nhau có ý nghĩa khi bổ sung các nồng độ MOS khác nhau. Mặc dù nghiên cứu của chúng tôi bước đầu cho thấy tính tích cực khi bổ sung MOS vào thức ăn của cá khoang cổ nemo, một số vấn đề vẫn cần nghiên cứu tiếp như: ảnh hưởng của MOS lên cá nuôi ở tình trạng sinh lý và bệnh tật, khả năng chống chọi với sự thay đổi của các yếu tố môi trường và các sinh vật gây bệnh. Nhìn chung nên bổ sung $0,15 \%$ mannan oligosaccharide vào thức ăn cho cá khoang cổ giai đoạn con non $(\sim 2 \mathrm{~cm})$.

Lời cảm ơn: Kết quả nghiên cứu là một phần của đề tài nghiên cứu ảnh hưởng MOS lên cá khoang cổ nemo, tại Viện Hải dương học. Các tác giả xin chân thành cảm ơn sự giúp đỡ của lãnh đạo Viện và những ý kiến đóng góp quý báu của các đồng nghiệp để hoàn chỉnh báo cáo này.

\section{TÀI LIẸU THAM KHẢO}

1. Akrami, R., Chitsaz, H., Hezarjaribi, A. and Ziaei, R., 2012a. Effect of Dietary Mannan Oligosaccharide (MOS) on Growth 
Performance and Immune Response of Gibel Carp Juveniles (Carassius auratus gibelio). J Vet Adv. 2, 507-513.

2. Akrami, R., Mansour, M. R., Chitsaz, H., Ziaei, R. and Ahmadi, Z., 2012b. Effect of Dietary Mannan Oligosaccharide on Growth Performance, Survival, Body Composition and Some Hematological Parameters of Carp Juvenile (Cyprinus Carpio). J. Anim. Sci. Adv. 2, 879-885.

3. Akrami, R., Razeghi Mansour, M., Ghobadi, S., Ahmadifar, E., Shaker Khoshroudi, M. and Moghimi Haji, M.S., 2013. Effect of prebiotic mannan oligosaccharide on hematological and blood serum biochemical parameters of cultured juvenile great sturgeon (Huso huso Linnaeus, 1754). Journal of Applied Ichthyology, doi: 10.1111/jai.12245.

4. Blaxhall, P. C. and Daisley, K. W., 1973. Routine haematological methods for use with fish blood. Journal of Fish Biology. 5, 771-781.

5. Daniels, C. L., Merrifield, D. L., Boothroyd, D. P., Davies, S. J., Factor, J. R. and Arnold, K. E., 2010. Effect of dietary Bacillus spp. and mannan oligosaccharides (MOS) on European lobster (Homarus gammarus L.) larvae growth performance, gut morphology and gut microbiota. Aquaculture. 304, 49-57.

6. Dimitroglou, A., Davies, S. and Sweetman, $J ., 2008$. The effect of dietary mannan oligosaccharides on the intestinal histology of rainbow trout (Oncorhynchus mykiss). Comparative Biochemistry and Physiology, Part A. 150, Abstract.

7. Dimitroglou, A., Moate, R., Janssens, T., Spring, P., Sweetman, J. W. and Davies, S. $J ., 2011 a$. Field Observations on the Effect of a Mannan Oligosaccharide on Mortality and Intestinal Integrity of Sole (Solea senegalensis, Kaup) Infected by Photobacterium damselae subsp. piscicida. J Aquac Res Development. S1, 013.

8. Dimitroglou, A., Reynolds, P., Ravnoy, B., Johnsen, F., Sweetman, J. W., Johansen, J. and Davies, S. J., 2011b. The effect of Mannan oligosaccharide supplementation on Atlantic salmon Smolts (Samo salar L.) Fed diet with high levels of plant proteins. Aquaculture Research \& Development. S1, $11 \mathrm{p}$.

9. Genc, M. A., Aktas, M., Genc, E. and Yilmaz, E., 2007. Effects of dietary mannan oligosaccharide on growth, body composition and hepatopancreas histology of Penaeus semisulcatus (de Haan 1844). Aquaculture Nutrition. 13, 156-161.

10. Gultepe, N., Salnur, S., HoŞSu, B. and Hisar, O., 2011. Dietary supplementation with Mannanoligosaccharides (MOS) from Bio-Mos enhances growth parameters and digestive capacity of gilthead sea bream (Sparus aurata). Aquaculture Nutrition. 17, 482-487.

11. Hai, N. V. and Fotedar, R., 2009. Comparison of the effects of the prebiotics (Bio-Mos ${ }^{\circledR}$ and $\left.\beta-1,3-D-g l u c a n\right)$ and the customised probiotics (Pseudomonas synxantha and $P$. aeruginosa) on the culture of juvenile western king prawns (Penaeus latisulcatus Kishinouye, 1896). Aquaculture. 289, 310-316.

12. Jagadeesh, T. D., Rather, M. A., Chethan, N., Divya, K. H. V. and Suresh, A. N., 2013. Effect of dietary supplementation of mannan oligosaccharide on water quality parameters in a recirculatory aquaculture system. European Journal of Experimental Biology. 3, 48-55

13. Jobling, M., 1983. A short review and critique of methodology used in fish growth and nutrition studies Journal of Fish Biology. 23, 685-703.

14. Nekoubin, H., Gharedaashi, E., Imanpour, M. R., Nowferesti, H. and Asgharimoghadam, A., 2012. The Influence of Synbiotic (Biomin imbo) on Growth Factors and Survival Rate of Zebrafish (Danio rerio) Larvae via Supplementation with Biomar. Global Veterinaria. 8, 503-506.

15. Peterson, B. C., Bramble, T. C. and Manning, B. B., 2010. Effects of Bio-Mos ${ }^{\circledR}$ on Growth and Survival of Channel Catfish Challenged with Edwardsiella ictaluri. Journal of the World Aquaculture Society. $41,149-155$. 
Đỗ Hữu Hoàng, Hoàng Đức Lư, ...

16. Ring $\phi, \quad E$., Olsen, $R$., Vecino, J., Wadsworth, S. and Song, S., 2012. Use of immunostimulants and nucleotides in aquaculture: a review. Journal of Marine Science: Research \& Development. 2, 104.

17. Sales, J. and Janssens, G. P. J., 2003. Nutrient requirements of ornamental fish. Aquatic Living Resources. 16, 533-540.

18. Sang, H. M. and Fotedar, R., 2010. Prebiotic Mannan Oligosaccharide Diet Improves Health Status of the Digestive

System of Marron, Cherax tenuimanus (Smith 1912). Journal of Applied Aquaculture. 22, 240-250.

19. Zhang, J., Liu, Y., Tian, L., Yang, H., Liang, $G$. and $X u, D ., 2012$. Effects of dietary mannan oligosaccharide on growth performance, gut morphology and stress tolerance of juvenile Pacific white shrimp, Litopenaeus vannamei. Fish \& Shellfish Immunology. $\quad 33, \quad 1,027-1,032$.

\title{
EFFECTS OF DIETARY MANNAN OLIGOSACCHARIDE ON MUSCLE PROTEIN, INTESTINAL MORPHOLOGY AND BLOOD CELL COUNT OF CLOWNFISH, AMPHIPRION OCELLARIS
}

\author{
Do Huu Hoang, Hoang Duc Lu, Pham Xuan Ky, Dang Tran Tu Tram, Nguyen Thi Kim \\ Bich, Ho Son Lam, Tran Van Huynh, Dao Viet Ha, Nguyen Thu Hong, Phan Bao Vi
}

\author{
Institute of Oceanography, VAST
}

\begin{abstract}
Clownfish, Amphiprion ocellaris $(2.4 \mathrm{~cm})$ were cultured in recirculation system, volume of $50 \mathrm{~L}$ and density of 20 fish per tank. Six levels of mannan oligosacharide (MOS), including $0.05 \%, 0.10 \%, 0.15 \%, 0.20 \%, 0.25 \%$ and $0.30 \%$ were supplemented to the control diet and fed to the fishfor 10 weeks. Collected data included ratio of internal and external intestinal perimeter of the gut (PR), muscle protein content and total blood cell count. Result showed that the $P R$ was highest in the fish fed by 0.1 and $0.15 \%$ MOS and lowest in two groups of fish fed by control and $0.3 \%$ MOS in their diet $(P<0.05)$. After 4 weeks of diet feeding, protein content in the fish among the treatments ranged from $12.85 \% P$ to $15.53 \%$. Those values seemed to increase at week 10 in compared to week 4, however; there was no significant difference in protein content among the treatments at either week 4 or week 10 measurements. Total blood cell count of fish at week 10 were highest in the group of fish fed on $0.05 \% \mathrm{MOS}\left(26.22 \times 10^{5} \pm 2.80 \times 10^{5} \mathrm{cells} / \mathrm{mm}^{3}\right)$, followed by the groups of fish fed $0.25 \%$ and $0.1 \%$ with blood count being $21.54 \times 10^{5} \pm 3.65 \times 10^{5} \mathrm{cells} / \mathrm{mm}^{3}$ and $20.73 \times 10^{5} \pm 7.88 \times 10^{5} \mathrm{cells} / \mathrm{mm}^{3}$. Respectively the lowest blood cell count was in the fish fed by $0.15 \%$ $\operatorname{MOS} \operatorname{MOS}\left(11,02 \times 10^{5} \pm 2,00 \times 10^{5}\right.$ cells $\left./ \mathrm{mm}^{3}\right)$. There was a statistically significant difference between blood cell count of fish fed by 0.05\% MOS in compared to fish fed by control diet and $0.15 \% \mathrm{MOS}(P<0,05)$.
\end{abstract}

Keywords: Clownfish, Amphiprion ocellaris, mannan oligosaccharide, gut morphology, protein, blood cell. 


\section{TẠP CHÍ KHOA HỌC VÀ CÔNG NGHỆ BIỂN Tập 14, Số 2 - 6-2014 \\ MỤC LỤC}

Nghiên cứu cấu trúc sâu, địa động lực và đánh giá độ nguy hiểm động đất và sóng thần trên vùng biển Việt Nam và kế cận Bùi Công Quế, Nguyễn Hồng Phuoong, Trần Thị Mỹ Thành, Trần Tuấn Dũng

Vùng cửa sông ở Hải Phòng - tài nguyên vị thế và tiềm năng phát triển Trần Đức Thạnh, Lê Đức An, Trịnh Minh Trang

Mô phỏng bản chất hoàn lưu ven đảo Bạch Long Vĩ bằng mô hình toán học Phạm Hải An, Trần Anh Tú

Đánh giá tính bền vững đới bờ - thí điểm tại huyện Phù Cát, tỉnh Bình Định Võ Thanh Tịnh, Chế Đình Lý, Luơng Văn Thanh

Đặc điểm biến động dòng chảy vùng ven bờ châu thổ sông Hồng - kết quả nghiên cứu từ mô hình 3D

Vũ Duy Vĩnh, Trần Đức Thạnh

A presence of a substance binding with the specific antibody against domoic acid in the thorny oyster Spondylus versicolor

Đào Việt Hà

Ảnh hưởng của mannan oligosaccharide bổ sung vào thức ăn lên protein trong cơ, hình thái ruột và tế bào máu của cá khoang cổ Nemo, Amphiprion ocellaris

Đỗ Hũu Hoàng, Hoàng Đức Lu, Phạm Xuân Kỳ, Đặng Trần Tú Trâm, Nguyễn Thị Kim Bích, Hồ Sơn Lâm, Trần Văn Huynh, Đào Việt Hà, Nguyễn Thu Hồng, Phan Bảo Vi

Đặc điểm sinh học sinh sản của ngao Bến Tre (Meretrix lyrata) tại vùng triều ven biển tỉnh Nam Định Nguyến Xuân Thành, Đỗ Công Thung

Ảnh hưởng của mật độ nuôi lên tốc độ tăng trưởng và tỷ lệ sống của cá ông tiên (Pterophyllum altum Pellegrin, 1930)

Hà Lê Thi Lộc, Nguyễn Thị Mỹ Dung

Một số đánh giá thống kê về tính chất của bão Biển Đông và vùng bờ biển Việt Nam giai đoạn 1951-2013

Du Văn Toán, Nguyễn Quốc Trinh, Phạm Văn Tiến, Luu Thị Toán

Mô phỏng một số kịch bản tràn dầu khu vực đảo Cồn Cỏ

Trần Anh Tú, Lê Đức Cường 


\section{JOURNAL OF MARINE SCIENCE AND TECHNOLOGY Vol. 14, No. 2 - June 2014 CONTENTS}

Study of the crustal structure, geodynamics and the earthquake and tsunami hazard assessment in Vietnam sea and adjacent areas

Bui Cong Que, Nguyen Hong Phuong, Tran Thi My Thanh, Tran Tuan Dung

Estuarine areas in Hai Phong city - position resources and potential for development Tran Duc Thanh, Le Duc An, Trinh Minh Trang

Simulating circulation nature around Bach Long Vi island by a mathemmatical model Pham Hai An, Tran Anh Tu

Sustainability assessment of coastal zone - a pilot in Phu Cat district, Binh Dinh province Vo Thanh Tinh, Che Dinh Ly, Luong Van Thanh

Characteristics of current variation in the coastal area of Red river delta - results of resaerch using the $3 \mathrm{~d}$ numerical model

Vu Duy Vinh, Tran Duc Thanh

A presence of a substance binding with the specific antibody against domoic acid in the thorny oyster Spondylus versicolor

Dao Viet Ha

Effects of dietary mannan oligosaccharide on muscle protein, intestinal morphology and blood cell count of clownfish, Amphiprion ocellaris

Do Huu Hoang, Hoang Duc Lu, Pham Xuan Ky, Dang Tran Tu Tram, Nguyen Thi Kim Bich, Ho Son Lam, Tran Van Huynh, Dao Viet Ha, Nguyen Thu Hong, Phan Bao Vi

The reproductive biology of lyrate asiatic hard clam (Meretrix lyrata) in the intertidal zone of Nam Dinh province

Nguyen Xuan Thanh, Do Cong Thung

Effect of stocking density on growth performance and survival rate of angel fish (Pterophyllum altum Pellegrin, 1930)

Ha Le Thi Loc, Nguyen Thi My Dung

A statistical analysis of typhoons in the period 1951 - 2013 in Vietnam's coastal zones Du Van Toan, Nguyen Quoc Trinh, Pham Van Tien, Luu Thi Toan

Simulation of some oil spill scenarios in Con Co island area

Tran Anh Tu, Le Duc Cuong 


\section{Tạp chí \\ Khoa học và Công nghệ Biển}

\section{Thể lệ viết và gửi bài}

1. Tạp chí Khoa học và Công nghệ Biển nhận đăng các bài viết về kết quả các công trình nghiên cứu điều tra cơ bản, nghiên cứu ứng dụng và triển khai, phát triển các phương pháp và công nghệ mới trong điều tra nghiên cứu, thông tin ngắn về các hội nghị, hội thảo và hoạt động liên quan ở trong và ngoài nước thuộc lĩnh vực khoa học và công nghệ biển.

2. Bài gửi đăng bằng tiếng Việt hoặc tiếng Anh trong dạng file điện tử soạn thảo bằng phần mềm Microsoft Word, font Times New Roman, cỡ chữ 12, cách dòng 1.2, hình và ảnh rõ ràng, có chú thích đầy đủ, kích thước hình vẽ và ảnh không quá $15 \times 20 \mathrm{~cm}$. Bài viết không quá 12 trang khổ $\mathrm{A} 4$ kể cả tóm tắt, bảng biểu, hình vẽ và tài liệu tham khảo. Bài viết ghi rõ họ tên tác giả và đồng tác giả, cơ quan công tác, địa chỉ liên hệ, điện thoại và email. Trong bài sử dụng các thuật ngữ khoa học và đơn vị đo lường hợp pháp và thông dụng của Việt Nam và quốc tế.

3. Tài liệu tham khảo: Bài gửi đăng phải có danh mục tài liệu tham khảo và phải được trích dẫn đầy đủ, rõ ràng trong bài. Mỗi tài liệu tham khảo trình bầy theo thứ tự: Họ và tên tác giả (đồng tác giả), năm xuất bản, tên bài báo hoặc tên sách, tên tạp chí hoặc nhà xuất bản sách, tập hoặc quyển, số, trang, nơi xuất bản sách. Các tài liệu tham khảo cần đánh số thứ tự và xếp theo trình tự trích dẫn trong bài. Đối với các tài liệu tham khảo thuộc hệ chữ la tinh giữ nguyên tên gốc, nểu thuộc hệ chữ tượng hình cần dịch ra tiếng Việt hoặc tiếng Anh và ghi chú tên hệ chữ nguyên bản. Các tài liệu lưu nội bộ như báo cáo đề tài, chuyên đề, các luận án, báo cáo khoa học tại các hội nghị, hội thảo không được xuất bản toàn văn ... không đưa vào danh mục tài liệu tham khảo, nếu cần có thể trích dẫn trực tiếp trong bài.

4. Tóm tắt: Mỗi bài gửi đăng phải có phần tóm tắt bằng tiếng Việt và tiếng Anh (Abstract). Tóm tắt phải ghi đủ tên bài báo, cung cấp đầy đủ, cô đọng thông tin về nội dung và kết quả đạt được trong bài báo với khối lượng không vượt quá 500 từ. Bên dưới tóm tắt cần ghi đủ các từ khóa.

5. Cam kết của tác giả: Ở dòng dưới cùng của trang cuối của bản thảo bài báo cần ghi rõ cam kêt: Trước khi gửi và trong thời gian chờ đăng ở tạp chí Khoa học và công nghệ biển tác giả không gửi đăng bài này cho tạp chí hoặc nhà xuât bản nào khác.

6. Tạp chí Khoa học và Công nghệ Biển không nhận đăng những bài viết không theo đúng các quy định nêu trên. Tạp chí cũng từ chối đăng những bài khi có yêu cầu sửa chữa của phản biện hoặc Hội đồng biên tập mà tác giả không chỉnh sửa, hoặc không có phản hồi tiếp thu, giải trình gựi về cho tòa soạn.

7. Địa chỉ liên hệ:Tòa soạn Tạp chí Khoa học và Công nghệ Biển, Nhà A16, Số 18 Hoàng Quốc Việt, Cầu Giấy, Hà Nội. Điện thoại: 04.37917411;01656080696. Email: jmst@vjs.ac.vn; tuandat86td@gmail.com. Website: http://vjs.ac.vn/index.php/jmst. 